azithromycin in 80 COVID-19 patients with at least a six-day follow up: A pilot observational study. Travel Med Infect Dis. 2020 Mar-Apr;34:101663. Epub 2020 Apr 11.

15. Molina JM, Delaugerre C, Goff J Le, Mela-Lima B, Ponscarme D, Goldwirt $L$, et al. No evidence of rapid antiviral clearance or clinical benefit with the combination of hydroxychloroquine and azithromycin in patients with severe COVID-19 infection. Médecine Mal Infect. 2020 Jun; 50(4):384. Epub 2020 Mar 30 [cited 2020 Apr 2]; Available from: https://linkinghub. elsevier.com/retrieve/pii/S0399077X20300858

16. Jun C, Danping L, Li L, Ping L, Qingnian X, Lu X, et al. A pilot study of hydroxychloroquine in treatment of patients with common coronavirus disease-19 (COVID-19). J Zhejiang Univ (Medical Sci). 2020 May 25;49(2):215-19. [Chinese]

17. Geleris J,Sun Y,Platt J,Zucker J,Baldwin M,Hripcsak G, et al.Observational study of hydroxychloroquine in hospitalized patients with Covid-19. N Engl J Med. 2020 May 7 [cited 2020 May 11];NEJMoa2012410. Available from: http://www.nejm.org/doi/10.1056/NEJMoa2012410

18. Rosenberg ES, Dufort EM, Udo T, Wilberschied LA, Kumar J, Tesoriero J, et al. Association of treatment with hydroxychloroquine or azithromycin with in-hospital mortality in patients with COVID-19 in New York State. JAMA. 2020 May 11[cited 2020 Jun 1]; e208630. Available from: http:// www.ncbi.nlm.nih.gov/pubmed/32392282

19. Mahévas $M$, Tran V-T, Roumier $M$, Chabrol A, Paule R, Guillaud $C$, et al. Clinical efficacy of hydroxychloroquine in patients with covid-19 pneumonia who require oxygen:observational comparative study using routine care data. BMJ. 2020 May 14 [cited 2020 May 18];369:m1844. Available from: http://www.bmj.com/lookup/doi/10.1136/bmj.m1844

20. World Health Organization."Solidarity" clinical trial for COVID-19 treatments. 2020 Jun 3[cited 2020 Jun 5]. Available from: https:// www.who.int/emergencies/diseases/novel-coronavirus-2019/globalresearch-on-novel-coronavirus-2019-ncov/solidarity-clinical-trial-forcovid-19-treatments

21. Roques $P$, Thiberville SD, Dupuis-Maguiraga L, Lum FM, Labadie K, Martinon $F$, et al. Paradoxical effect of chloroquine treatment in enhancing chikungunya virus infection. Viruses. 2018 May 17 [cited 2020 Apr 2];10(5).268. Available from: http://www.ncbi.nlm.nih.gov/ pubmed/29772762

22. Paton NI, Lee L, Xu Y, Ooi EE, Cheung YB, Archuleta S, et al.Chloroquine for influenza prevention: A randomised, double-blind, placebo controlled trial. Lancet Infect Dis. 2011 May 5;11(9):677-83.

23. Paton NI, Goodall RL, Dunn DT, Franzen S, Collaco-Moraes Y, Gazzard BG, et al. Effects of hydroxychloroquine on immune activation and disease progression among HIV-infected patients not receiving antiretroviral therapy: A randomized controlled trial. JAMA. 2012 Jul 25 [cited 2020 Apr 2];308(4):353-61. Available from: http://www.ncbi.nlm.nih.gov/ pubmed/22820788

24. Choy KT, Wong AYL, Kaewpreedee P, Sia SF, Chen D, Hui KPY, et al. Remdesivir, lopinavir, emetine, and homoharringtonine inhibit SARSCoV-2 replication in vitro. Antiviral Res. 2020 Jun 1;178:104786.

25. Young BE, Ong SWX, Kalimuddin S, Low JG, Tan SY, Loh J, et al. Epidemiologic Features and Clinical Course of Patients Infected with SARS-CoV-2 in Singapore. JAMA. 2020 Apr 21;323(15):1488-94.

26. Cao B,Wang Y,Wen D, Liu W, Wang J,Fan G, et al.A trial of lopinavir-ritonavir in adults hospitalized with severe Covid-19. N Engl J Med. 2020;1-13. Available from: http://www.ncbi.nlm.nih.gov/pubmed/32187464

27. WHO Evidence Review Group. The cardiotoxicity of antimalarials. Geneva: WHO-ERG;2016 Oct13-4 [cited 2020 Apr 2]. Available from: http://www.who.int/malaria/mpac/mpac-mar2017-erg-cardiotoxicityreport-session2.pdf

28. Hydroxychloroquine: Drug information.UpToDate. Date unknown[cited $2020 \mathrm{Apr}$ 3]. Available from:https://www.uptodate.com/contents/ hydroxychloroquine-drug-information?source=autocomplete\&index= $0 \sim 1$ \&search=hydr\#F180902

29. Shankar SP, Uma Sudhan E, Reddy KHV, Singh R, Ramya N. Prevalence of obesity and diabetes among health care physicians in Pondicherry, India. Int J Adv Med. 2019 May 24;6(3):646.

30. Hegde SK, Vijayakrishnan G, Sasankh A, Venkateswaran S, Parasuraman G. Lifestyle-associated risk for cardiovascular diseases among doctors and nurses working in a medical college hospital in Tamil Nadu, India. J Family Med Prim Care. 2016 Apr-Jun;5(2):281-5.

31. Nag T, Ghosh A. Cardiovascular disease risk factors in Asian Indian population: A systematic review. J Cardiovasc Dis Res. 2013 Dec;4(4):2228.29.

32. Danon L, Brooks-Pollock E, Bailey M, Keeling MJ. A spatial model of CoVID-19 transmission in England and Wales: early spread and peak timing. medRxiv. 2020 Feb 14 [cited 2020 Apr 3]; doi:10.1101/2020.02.1 2.20022566. Available from: https://www.medrxiv.org/content/10.1101 /2020.02.12.20022566v1

33. Chatterjee P, Anand T, Singh K, Rasaily R, Singh R. Healthcare workers \& SARS-CoV-2 infection in India: A case-control investigation in the time of COVID-19. Indian J Med Res. 2020 May 28 [cited 2020 Jun 1];DOI: 10.4103/ ijmr.IJMR_2234_20 Epub ahead of print. Available from: http://www. ijmr.org.in/preprintarticle.asp?id=285520

\title{
"Slow research" in the time of Covid-19
}

\section{SHUBHA RANGANATHAN}

\section{Abstract}

This commentary reflects on what it means to do public health and social science research in a post-Covid world. Given the global urgency brought on by the pandemic, it appears as if any kind

Author: Shubha Ranganathan (shubha@la.iith.ac.in), Associate Professor Department of Liberal Arts, Indian Institute of Technology Hyderabad, Telangana 502285 INDIA.

To cite: Ranganathan S. "Slow research" in the time of Covid-19. Indian J Med Ethics. 2020 Jul-Sep; 5(3) NS: 212-4. DOI: 10.20529/IJME.2020.072.

Published online on July 2,2020.

Manuscript Editor: Sandhya Srinivasan.

(c) Indian Journal of Medical Ethics 2020 of non-Covid research has become redundant or meaningless. Yet, in many ways, the pandemic has highlighted the need to go back to many of the old lessons in the social sciences and public health. Here, I draw on the concept of "slow research" in global health to foreground some of these principles - the need to pay attention to local contexts and particularities, the importance of time to contemplate on the complexity of findings, and the need to think beyond global agendas that seek quick findings and globally scalable solutions, and focus on what is socially relevant in different local contexts. While not cast in opposition to rapid research, slow research is an important alternative, particularly in pandemic times.

\section{"Slow research" in the time of Covid}

What does it mean to do public health and social science research in a post-Covid world? How do we understand what 
we even mean by the term "research" anymore, at a time when the focus seems to be solely on the bare "essentials"? At a time when Covid-19 has become the primary lens through which all of reality is experienced, academics everywhere are talking about everything Covid. It appears as if all other research work in progress or under planning has been dropped in order to take on the research challenges posed by the pandemic Thus, biomedical researchers seem to be invested in the development of drugs, vaccines, or ventilators; epidemiologists, statisticians, virologists, and others are modelling the path of the virus across the globe; economists are measuring and speculating about the impact on economies, livelihoods, and markets; psychologists are contemplating on the mental health and psychological ramifications of the pandemic; anthropologists and sociologists are considering how media exposure, as well as judgements of risk, uncertainty and fear impact people's notions of health, illness, and disease. Every new day brings forth not just new research findings in our daily capsules of health news, but also information about webinars on Covid-19, calls for Covid-19 research projects, resources for "teaching the virus" in the classroom, not to speak of the dramatic surge in Covid-19 published material. Academic journals seem to be intent on publishing anything related to Covid-19, on occasion even without peer-review. The pace of these developments is reflective of the collective heightened urgency about making sense of the pandemic in whatever way possible.

It is as if all non-Covid research has suddenly receded backstage, ashamed of its meaningless existence at a time of worldwide crisis. In some ways, this is perhaps not a bad thing for it is making us sit up and question everything that we knew about the world and about the social. If a global pandemic that within a span of a few months, has dramatically transformed our everyday lives, work, families, and social relations does not also impact the way we think about research, then we have to ask ourselves serious questions about the relevance of social science research.

And yet, perhaps it is also time to ponder about what all this could mean for the way in which we carry out public health and social science research in a post-Covid world. Are we increasingly moving towards a research culture of rapid research on current topics, seeking to obtain quick findings of worldwide relevance? What does this mean for "slow research", and indeed, for the slow science movement overall? In their article on the need for a new movement of slow research in the field of global health, Adams, Burke and Whitmarsh (1) emphasise the importance and value of pauses in social science research, pauses which enable us to appreciate the complexity of the moment. As they point out, "In academic and activist fields of global health today, we are all being asked to be productive in ways that create a sense of having to do more and to do it faster, to multitask for survival in a global workplace, to always be thinking of the next big thing, to scale up and implement, often even before we have completed our tasks at hand." (1: p 180). In turn, these pressures mean that we only engage in research on issues which are deemed relevant globally, which can be scaled up unproblematically, and on topics that will capture the attention of global funding institutions. Yet, without paying attention to local contexts and particularities, there is little impact that social science research can have on public health policy and practice. As the authors clarify:

Slow research is not necessarily opposed to 'fast' research, but it is opposed to what might be identified as a new normal. Slow research is a response, addition, and possible alternative to the newest normative trends. It entails working with an ethic or set of values and strategies that valorize different things from the emergent norms (p. 180).

Here, they draw from the slow food movement, as well as from the slow science movement in Europe, emphasising the need for undertaking research without being burdened by the pressures of producing quick results that have significant global impact. In her landmark book Another science is possible: A manifesto for slow science, Isabelle Stengers calls for an "alternative science", a science that is not afraid of public engagement and scrutiny and that resists conformism, competitiveness, and opportunism (2). Importantly, Stengers flags the need for scientists to be socially relevant. In their article, Adams, Burke and Whitmarsh draw inspiration from some primary tenets of the slow food movement. For instance, the slow food approach of consuming food that derives from local produce would translate into the focus on local ecologies and economies in public health and social science research. Similarly, they call attention to another slow food principle - deliberative temporality - or, "the pause" before eating. For research, this would mean taking pauses before the research process to reflect on the emerging ideas and findings.

For instance, in the case of the Covid pandemic, it is already becoming clear that there are variations across the global North and South, in terms of the impact of the pandemic and its after-effects. Thus, some global health scholars like Richard Cash and Vikram Patel have argued that most of the measures which have been rolled out in many nations to address the pandemic, such as lockdowns, reliance on high-cost testing, and emphasis on tertiary hospital care are technical solutions that might make sense in global North contexts but have little relevance in resource-constrained global South settings (3). Instead, they maintain, it is important for communities and nations in the global South to resume normal activities with adequate precautions in order to prevent economic and health crises much worse than the pandemic (3). On the other hand, based on his personal experience of becoming infected with Covid-19, the virologist Peter Piot, director of the London School of Hygiene and Tropical Medicine, swears by the need to take the virus seriously and invest in developing a vaccine, without which, according to him, there is little hope for humanity (4).

There are several examples of such divergent views, which begin to make sense when one looks at the contexts and settings from which they emerge. Given that the impact of the virus is so variable across the UK and India, it is not 
surprising that a disease that is capable of producing an emergency scenario in the UK might turn out to be only one among multiple competing threats to good health and survival in India. That is where it becomes important to focus on the local variations and particularities, something that can only be achieved by investing time and care in communities. Despite the pressure to measure and speak the language of numbers, which have high authoritative power in the field of global health (5), it is also important to recognise the value of long-term, in-depth, qualitative research - slow research. This is not to suggest that longitudinal or in-depth research cannot be conducted in quantitative frameworks. Yet, qualitative research is particularly suited to such long-term investments in local fields.

Importantly, as Adams, Burke and Whitmarsh (1) clarify, slow research is not in opposition to rapid research. Clearly, there are important crises brought on by the pandemic which demand urgent solutions. At the same time, they point out that rapid research is fast becoming the new normal, and this is what requires pause for reflection. The irony here is that while, in many ways, responses to the pandemic sought to slow things down, and there were initial indications of this "slowing down" taking place, it now seems to be doing the opposite. We seem to have got back on track, with online teaching, video conferences, webinars, and working on new Covid-19 research grants and proposals.

And what of these new research ideas? The paradox is that while all non-Covid research seems irrelevant in the current scenario, in many ways, the Covid situation is highlighting that it is actually the long-standing lessons of the social sciences that are increasingly relevant - the importance of transparency in governance, the role of media in shaping our health notions, the structural inequalities of class, gender, and race that impact health, the global threats of climate change - one could go on.
While cutting-edge biomedical research is urgently required, clearly, the devastating impact of the pandemic and its after effects have much to do with the social and cultural contexts of health and illness. The pandemic is giving us a crash course on all these issues.

Where does that leave us? We are at a point where we have no way of determining any end dates to the pandemic; we have no idea when (and if) the pandemic will "end". Perhaps it will not pass but only change things forever; perhaps we will move towards a different kind of normal, but at this point of time we have no reference as to what that may look like. Yet, even if it forever changes everything about the world as we know it, it may be worthwhile to pause for a moment and reflect on the significance of the Covid moment, before (or even while) jumping unthinkingly onto the Covid research bandwagon. As outlined in the slow science manifesto online (6), "Science needs time to think. Science needs time to read, and time to fail." The question is, whether we are willing to take out that time.

\section{References}

1. Adams V, Burke N, Whitmarsh I. Slow research: Thoughts for a movement in global health. Med Anthropol. 2014; 33(3): 179-97. DOI: 10.1080/01459740.2013.858335.

2. Stengers I. [Muecke S, translator]. Another science is possible. A manifesto for slow science. Cambridge, UK: Polity Press; 2018.220 pp.

3. Cash R, Patel V. Has COVID-19 subverted global health? Lancet. 2020 May 3-Jun 5; 395(10238): 1687-8. DOI: https://doi.org/10.1016/S01406736(20)31089-8.

4. Draulans D.'Finally, a virus got me.' Scientist who fought Ebola and HIV reflects on facing death from COVID-19. Science. 2020 May 8[cited 2020 May 10]. Available from: https://www.sciencemag.org/news/2020/05/ finally-virus-got-me-scientist-who-fought-ebola-and-hiv-reflectsfacing-death-covid-19

5. Adams V, editor. Metrics: What counts in global health. Durham: Duke University Press. 2016.258 pp.

6. Slow Science Academy. The Slow Science Manifesto. 2010[cited 2020 May 11]. Available from: http://slow-science.org/

\section{Be a part of IJME}

IJME invites readers to submit research studies, comments, case studies, reports, reviews, letters, as also poems, short stories, original paintings and photographs of print quality ( both in colour and B/W) to be considered for publication.

All submitted matter is subject to peer review.

Contributors are neither paid nor charged any fee for published matter. 